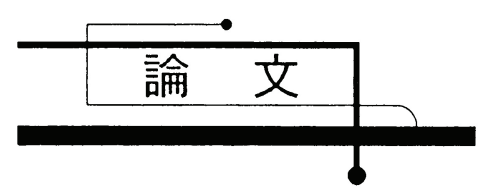

\title{
気液二相噴流の変形挙動に関する実験的検討*
}

\section{Experimental Investigation of the Deformation of Gas-Liquid Two-Phase Jet}

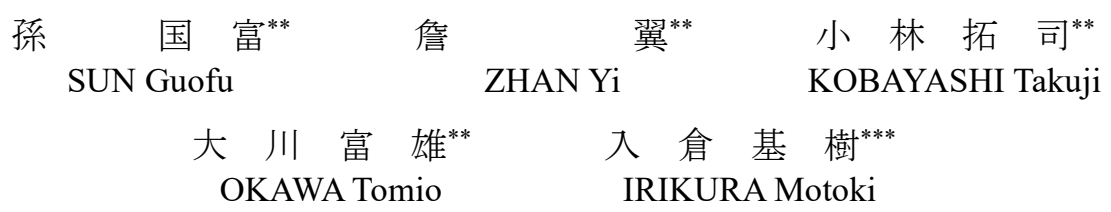

\begin{abstract}
When a gas-liquid two-phase jet is discharged from a nozzle, its surface is fairly smooth for a certain distance from the nozzle exit. Then, deformation develops to cause jet breakup eventually. The deformation length that is defined as the length required for the jet deformation to develop is of industrial importance since significant splashing occurs when deformed jet impinges on a solid surface. The present work investigated the deformation length experimentally using air and water as the test fluids. The flow direction was vertical downward, and annular liquid film was formed at the nozzle exit. It was shown that the deformation develops faster with an increase in the gas flow rate. The measured deformation lengths were about 28.5 times the liquid film thickness estimated at the nozzle exit and no noticeable influence of the Weber number was found.
\end{abstract}

Keywords: Gas-liquid two-phase jet, Deformation length, Splashing, Characteristic length

\section{1. 緒 言}

\section{1 研究背景}

化学プラントでは、Fig. 1 に示すように、気液 二相噴流を容器の内壁に衝突させることで、簡易 的に気液分離を行う場合がある。Fig. 1(a)に示す ように、気液混合体は配管を通して気液分離器の 内部に設置された円筒容器に送られ、その側面に 設けられた複数の円形孔から噴出する。その後、 Fig. 1(b)の断面図に示寸ように、気液分離器の内 壁に衝突して、液体は壁面に沿って重力により流 下、気体は気液分離器の上部に設置された気体配 管より流出して、気液分離を完了寸る。ただし、 気液二相噴流が内壁に衝突する際に、様々なサイ ズの液滴が飛散（スプラッシュ）する可能性があ る[1]。このとき、生成液滴のサイズが十分に大き ければ、重力により落下して容器の下部に形成さ れるプール内に取り込まれると期待できるが、小
さい場合には、気流中に取り込まれて、上部の気 体配管から流出（キャリーオーバー）する恐れが ある。この結果、気液分離効率が低下し、後続の 設備に悪影響を与える。したがって、化学プラン 卜の性能劣化を防止する上で、二相噴流が固体壁 に衝突したときに生成される液滴の総量と径分 布を正確に予測する技術が必要である。

\section{2 文献調查}

\subsection{1 液単相噴流に関する先行研究}

液単相噴流に関する知見は、二相噴流の挙動を 検討するためのベースとなる。Kim ら[2]は、ノズ ルより鉛直下向きに流出する液単相噴流が水平 固体面と衝突する場合を対象に、液体流量と衝突 距離（ノズルと水平固体面の距離）が飛散率に及 ぼす影響を調べている。この結果、衝突距離が噴 流の分裂長さ (噴流が分裂を開始するまでに要す る長さ）よりも長く、分裂した噴流として固体面

\footnotetext{
* 2020.10.20 受付

** 電気通信大学情報理工学研究科 $\overline{1} 182-8585$ 東京都調布市調布ヶ丘 1-5-1

TEL: (042)443-5597 E-mail: sunguofu@eel.mi.uec.ac.jp

*** 千代田化工建設株式会社
} 
に衝突する場合、未分裂の場合よりも飛散率 (噴 流の流量に対する飛散液滴量の割合) が著しく大 きくなることを報告している。

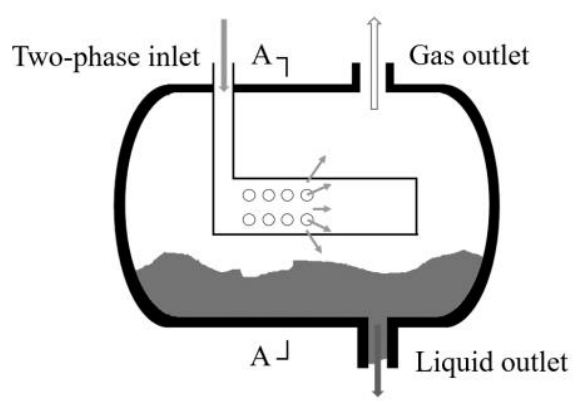

(a) Side view

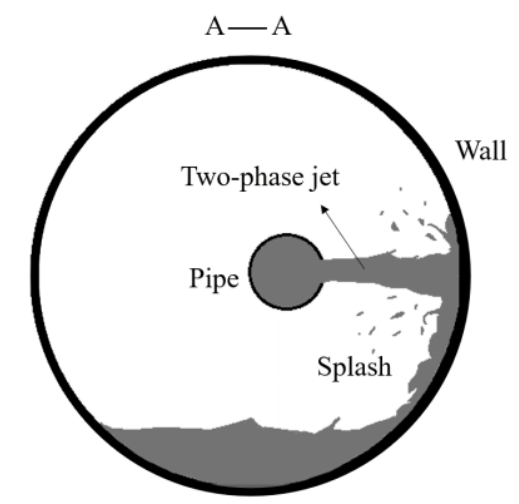

(b) Cross-sectional view at A-A in Fig. 1(a)

Fig. 1 Schematic diagram of gas-liquid separator used in chemical plants.

これは、噴流の分裂によって生じた一次液滴が、 固体面上に形成された液膜に衝突する際に、激し い液滴飛散が起こるためと解釈できる。したがっ て、噴流衝突時の液滴飛散現象について考える場 合、分裂長さに関する知見はきわめて重要である。

液単相噴流の分裂挙動については、Rayleigh に よる先駆的な理論解析 [3] の後、液流量が分裂長さ に及ぼす影響[4]や、Plateau-Rayleigh 不安定波長 と分裂後の液滴サイズの関係[5]等が調べられて いる。近年、Zhan ら[6-8]は、鉛直下向きに流出 する液単相噴流が水平固体面に衝突する場合を 対象に、分裂長さを精密に定義することで、液体 の流量や物性值が飛散率に及ぼす影響を良好に 相関できることを示している。Fig. 2 に、Zhan ら の考え方を模式的に示す[6]。ノズルを流出した後
に噴流が最初に分裂を生じる位置は、時間的に変 動する。このため、最初に分裂を生じる位置の時 間的な最小值を最小分裂長 $L_{1}$ と定義する。 $L_{1}$ の

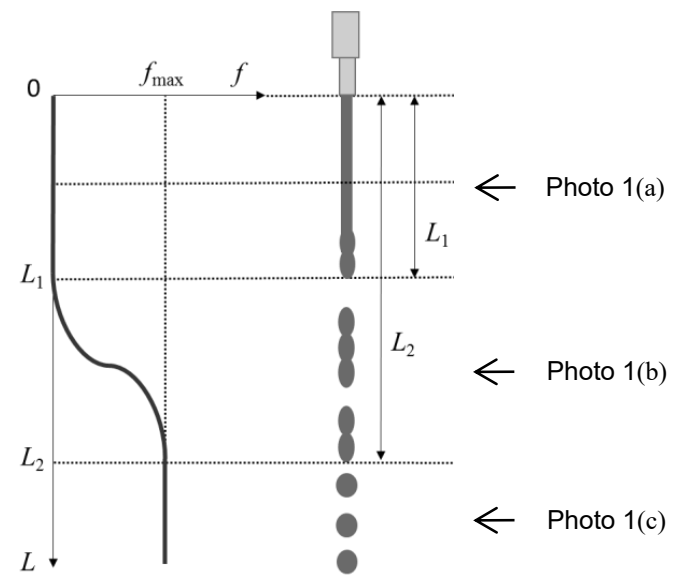

Fig. 2 Definitions of the breakup lengths for singlephase liquid jet utilized by Zhan et al. [6].

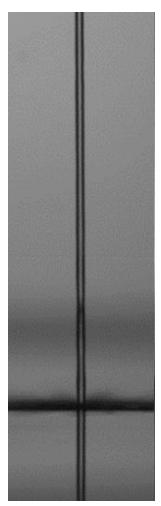

(a) $L<L_{1}$

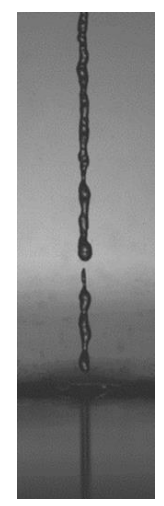

(b) $L_{1}<L<L_{2}$

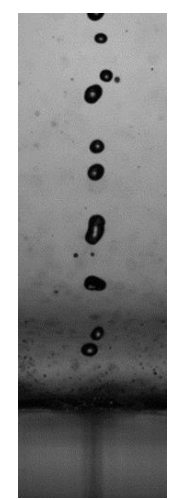

(c) $L>L_{2}$
Photo 1 Splashing during liquid jet impingement at the three fall heights shown in Fig. 2 [8].

下流では、噴流がさらに分裂を継続して、一次液 滴の通過頻度 $f$ が徐々に増加するが、ある距離に 達すると、分裂が完了して、 $f$ が一定值 $f_{\max }$ とな る。この位置を最大分裂長さ $L_{2}$ と定義する。

Zhan らは、飛散率は $f$ に比例するため、ノズル からの距離 $L$ が、 $L<L_{1}$ では液滴飛散は無視でき るが、 $L_{1}<L<L_{2}$ では漸近的に増加し、 $L>L_{2}$ で

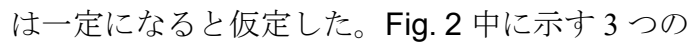
位置における液滴飛散状況を Photo 1(a)〜 (c)に 各々示す。Zhan らが指摘するように、液噴流の分 裂の進展とともに、液滴飛散が激しくなる様子が 
確認できる $[8]$ 。

\subsection{2 二相噴流に関する先行研究}

気液二相噴流に関する知見は、液単相噴流と比 較してきわめて少ない。このため、Zhan ら[9]は、 二相噴流の場合でも、単相噴の場合と同様に、 $L$ $<L_{1}$ であれば液滴飛散は少ないと仮定して、二相 噴流を対象に $L_{1}$ の計測を実施した。この結果、二 相噴流の場合の $L_{1}$ は、ノズル出口で評価される 液膜厚さと概ね比例関係にあることを見い出し、 $L_{1}$ に関する相関式を提案している。

\section{3 本研究の目的}

Photo 2 に、Zhan ら[9]が、気液二相噴流の分裂 長さ $L_{b}$ が時間的に変化する様子を観察した結果 の一例を示す。単相噴流の場合、Photo 1(a)に示 したように、分裂前における噴流の変化はきわめ て小さい。一方、Photo 2 より、気液二相噴流の 場合には、分裂開始前から噴流の大規模な変形が 生じることがわかる。噴流の変形部分が固体壁上 に形成された液膜に衝突すると、噴流の分裂によ って生成した一次液滴が衝突する場合と類似し た状況となり、この結果、顕著な液滴飛散を生じ得

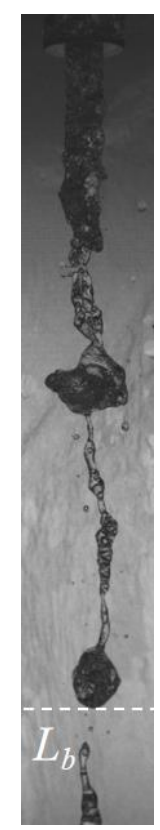

$t=0 \mathrm{~ms}$

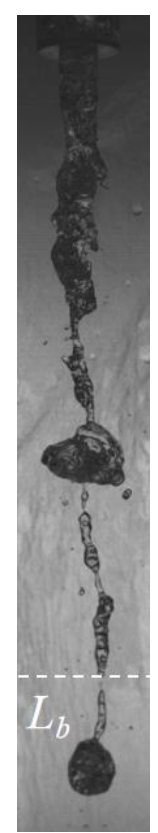

$t=30 \mathrm{~ms}$

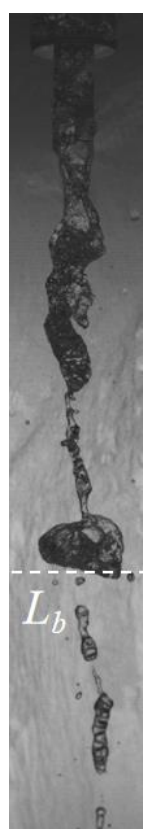

$t=60 \mathrm{~ms}$

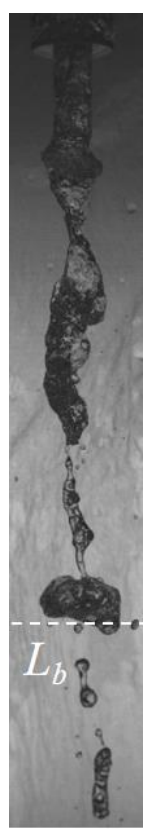

$t=90 \mathrm{~ms}$
Photo 2 Transient of the instantaneous breakup length $L_{b}$ for the gas-liquid two-phase jet [9].
ると考えられる。このため、Zhan ら[9]の仮定と は異なり、 $L<L_{1}$ であっても無視できない程度の 液滴飛散が生じる可能性がある。

Fig. 1 に示寸気液分離器でキャリーオーバーを 生じないためには、気液二相噴流が固体壁に衝突 した場合に、顕著なスプラッシュを生じない条件 を特定することがまず重要である。このため、本 研究では、気液二相噴流の変形と液滴飛散量の関 係を実験的に調べる。さらに、顕著な液滴飛散を 起こすような大規模変形を生じるのに要する距 離を調心、無次元相関式として取り纏める。

\section{2. 実験方法}

\section{1 流動状況の観察}

実験装置の構成を Fig. 3(a)に示す。液体と気体 は、各々ポンプとコンプレッサーを用いて混合器 に送られ、その下部に設けられた円形ノズルより 鉛直下向きに噴出する。混合器の構造を Fig. 3(b) に示す。混合器は、内径 $41 \mathrm{~mm}$ 、長さ $350 \mathrm{~mm}$ の 円筒形で、その上部より気体が流入する。一方、 液体は、混合器の中部側面に設けた直径 $3 \mathrm{~mm}$ の 24 個の円形孔より流入する。気液混合体は、混合 器下部の円形端面の中央に設けられた直径 20 $\mathrm{mm}$ 長さ $30 \mathrm{~mm}$ の円形ノズルから噴出する。Fig. 3(a)に示すように、気液混合体は、気液混合器の 下部に設置した矩形の貯水タンク内に流下し、気 体は重力によって大気中に分離、液体はポンプに より循環される。

噴流の流動状況観察は、高速度カメラを用いて 行った。この際、空間解像度は $500 \mu \mathrm{m} / \mathrm{pixel}$ 、撮

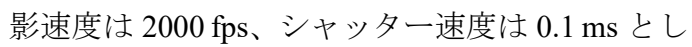
た。液温は矩形容器内で計測精度 $\pm 0.5 \mathrm{~K} の \mathrm{~K}$ 型 熱電対により、気体流量と液体流量は、各々計測 精度 $\pm 5 \mathrm{~L} / \mathrm{min}$ の面積式流量計と計測精度 $\pm 0.5 \mathrm{~L} / \mathrm{h}$ のタービン式流量計を用いて計測した。

次に、二相噴流が固体面と衝突する際の液滴飛 散状況を観察する場合には、矩形タンクの直上に 一辺が $200 \mathrm{~mm}$ のステンレス製正方形板を衝突板 として配置した。衝突距離の調整は、Fig. 3(a)に 模式的に示すように、気液混合器を上下に移動す ることにより行った。本実験では、液滴の飛散状 況を詳細に観察するため、空間解像度を 160 $\mu \mathrm{m} /$ pixel とした。

実験条件は、試験流体には室温 $\left(20^{\circ} \mathrm{C}\right)$ の水と 空気を用いた。化学プラントの気液分離器におけ 
る典型的な流動条件を参考にして、ノズル部にお ける液体の体積流束 $J_{l}$ は $0.27 \sim 0.75 \mathrm{~m} / \mathrm{s}$ 、気体の 体積流束 $J_{g}$ は $2.65 \sim 10.61 \mathrm{~m} / \mathrm{s}$ の範囲で設定した。

なお、Fig. 3(b)に示す気液混合器の構造及び $J_{g}$ が $J_{l}$ よりも数倍程度以上大きいことから、ノズル の出口では、環状流もしくはこれに近いフローパ ターンが形成されると予想される。

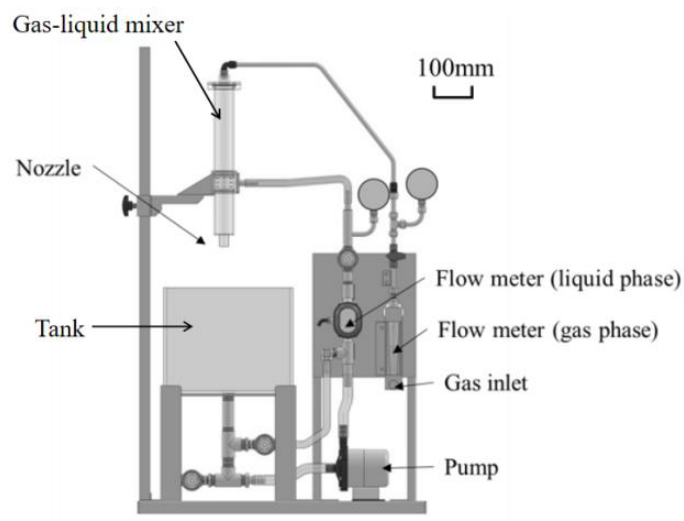

(a) Overview

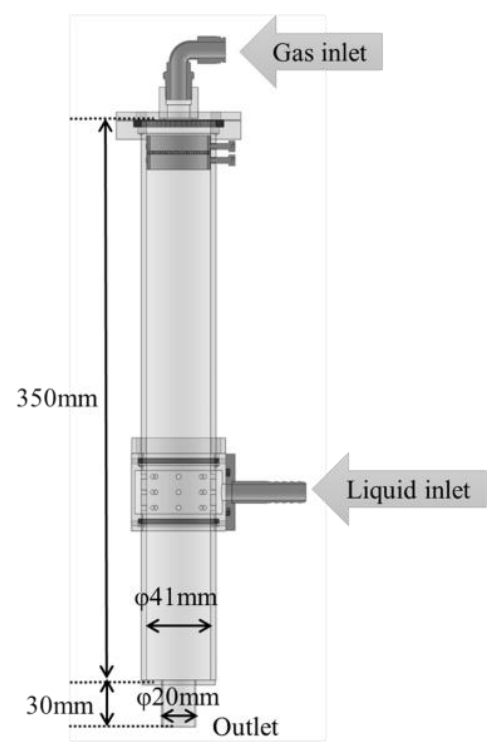

(b) Gas-liquid mixer

Fig. 3 Schematic diagram of experimental apparatus.

\section{2 飛散率計測}

液滴飛散率の計測方法を Fig. 4 に示す。Fig. 4(a), (b) に示すように、一辺が $118 \mathrm{~mm}$ のステン レス製の正方形枠にビニール袋をかぶせて液滴捕

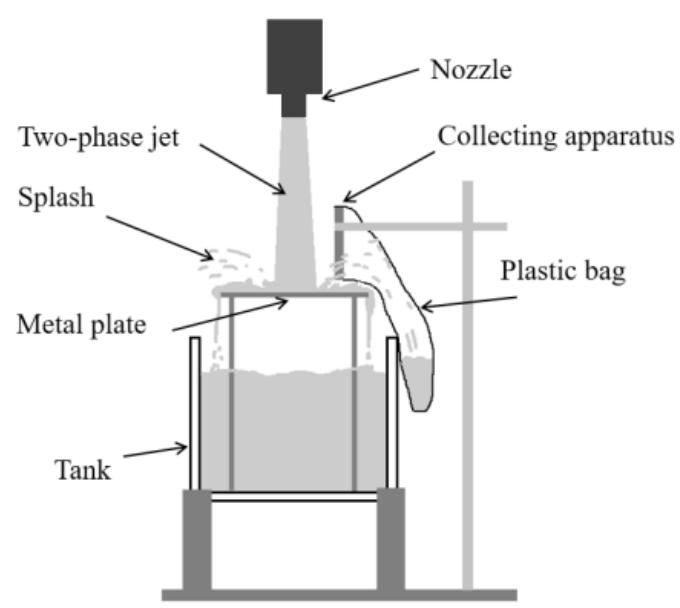

(a) Arrangement of droplet collecting device

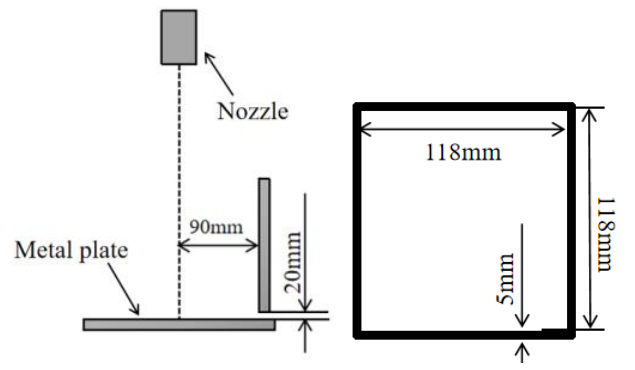

(b) Location and dimension of the collecting device

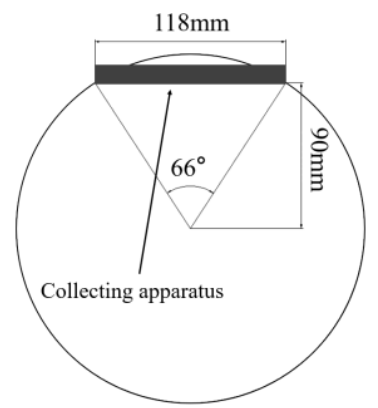

(c) Collecting angle

Fig. 4 Measurement method of the splash rate.

集器とし、衝突板の中心から $90 \mathrm{~mm}$ の位置に配 置した。Fig.4(b) に示すように、衝突板と液滴捕 集器の間には $20 \mathrm{~mm}$ のギャップを設けた。この 構成により、衝突板上に形成される液膜は貯水夕 ンクに流下し、液滴捕集器の枠内に飛来する液滴 はビニール袋内に捕集される。捕集時間は、気液 の流量条件に応じて 15 30 秒とし、液滴捕集量 
は実験前後の液滴捕集器の重量差より算出した。 重量計の計測誤差より、液滴捕集量の計測誤差は $\pm 5 \%$ 以内と見積もられた。

本手法では、液滴捕集器が噴流や衝突板上に形 成される液膜と干渉しないこと、飛散液滴を確実 に捕集できることが求められる。このため、液滴 捕集器のサイズと設置位置は、高速度カメラを用 いた噴流、液膜、飛散液滴の挙動の観察結果に基 づいて決定した。Fig.4(c) は、正方形枠と衝突板 の位置関係を示す上面図である。捕集角度は $66^{\circ}$ であるため、実験装置の構造より軸対称性を仮定 して、液滴捕集量に 360/66=5.45 を乗じて全液滴 飛散量とした。また、液滴飛散率 $S p^{*}$ を、単位時 間当たりの液滴飛散量 $Q_{s p l a s h}$ の液体流量 $Q_{l}$ に対 する比として、次式により定義した。

$$
S p^{*}=\frac{Q_{\text {splash }}}{Q_{l}}
$$

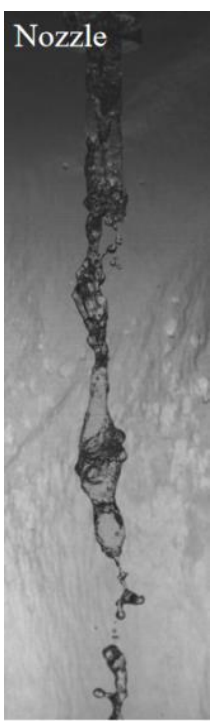

(a) $J_{l}=0.53 \mathrm{~m} / \mathrm{s}$ $J_{g}=2.65 \mathrm{~m} / \mathrm{s}$

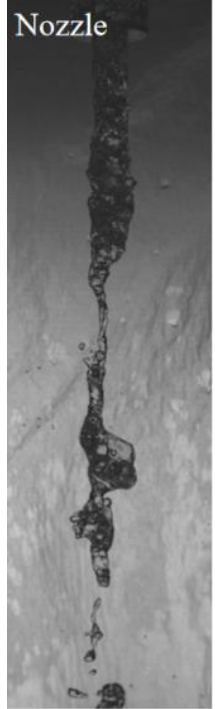

(b) $J_{l}=0.66 \mathrm{~m} / \mathrm{s}$ $J_{g}=2.65 \mathrm{~m} / \mathrm{s}$

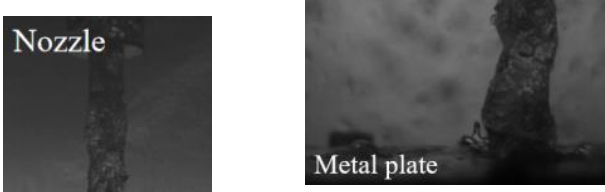

(a) $L=100 \mathrm{~mm}$

顕著ではない。しかし、ノズルからの距離が増加 するにつれて徐々に変形の程度が激しくなり、最 終的に分裂して多数の液滴あるいは液塊を生じ ている。

Photo 4 は、Photo 3(b)の条件で衝突板を設置 して、液滴飛散の様子を観察した結果である。衝 突距離 $L$ が十分短い場合には、Photo 4(a)に示す ように液滴飛散は無視できる程度であるが、 $L$ が 増加して噴流の変形が激しくなると、Photo 4(b) に示すように、噴流の分裂が生じる以前であって も、顕著な液滴飛散が生じることが確認された。 本観察結果に基づき、液滴飛散を開始するときの $L$ を変形開始長さ $L_{d}$ と定義する。

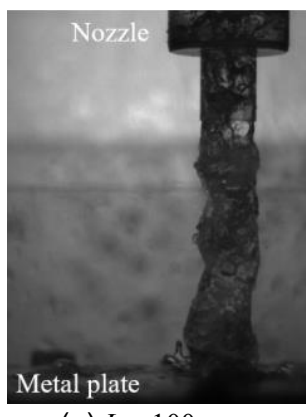

Photo 4 Effect of the fall height on the production of secondary droplets during gas-liquid two-phase jet impingement $\left(J_{l}=0.66 \mathrm{~m} / \mathrm{s}\right.$, $J_{g}=2.65 \mathrm{~m} / \mathrm{s}$ ).

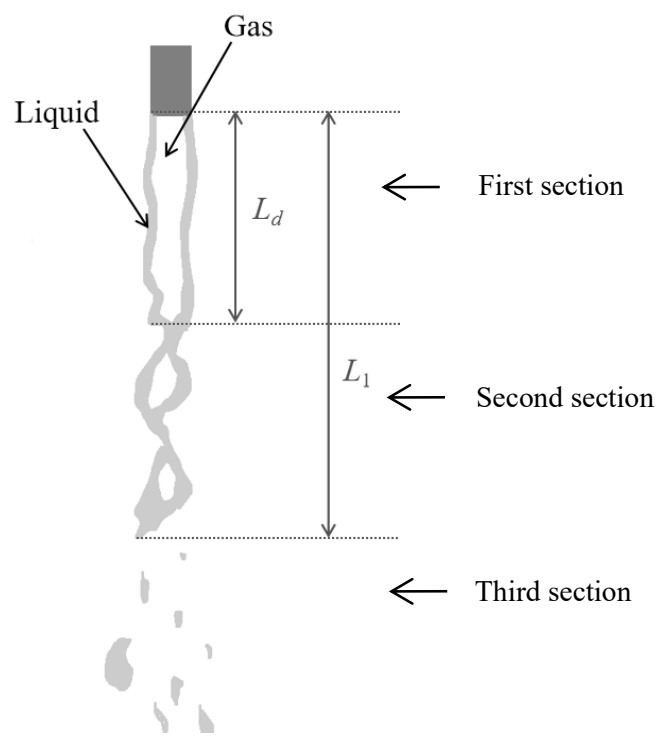

Fig. 5 Three sections of two-phase jet. 
以上の考察より、気液二相噴流は、Fig. 5 に示 す 3 つの部分に分けられる。 $0<L<L_{d}$ の第一部 分では、噴流の変形の程度は小さく、固体面に衝 突しても液滴の飛散は無視できる程度である。 $L d$ $<L<L_{1}$ の第二部分では、噴流の変形が激しくな り、変形部分が固体面に衝突すると、その衝撃に よって顕著な液滴飛散が生じる。 $L>L_{1}$ の第三部 分では、噴流が液滴及び液塊に分裂するため、こ れらが固体と衝突するときに、多量の液滴飛散を 生じる。化学プラントの気液分離器では、二相噴 流が固体壁に衝突する際に液滴飛散が生じない ことが望ましい。したがって、実質的な液滴飛散 開始位置である変形開始長さ $L_{d}$ は、気液分離器 の設計を行う上で重要な物理量と言える。

\section{2 気液二相噴流の変形率}

二相噴流が固体面と衝突するとき、噴流の変形 が十分に激しくなると、液滴飛散を開始する。こ れより、 $L_{d}$ は噴流の変形の程度から測定できると 考えられる。本研究では、単位時間当たりの噴流 幅の変化割合により変形の程度を表せると仮定 して、瞬時の変形率 $f_{\text {def }}$ を次式で定義する。

$$
f_{\text {def }}(t, L)=\frac{W(t, L)-W(t-\Delta t, L)}{W(t, L) \Delta t}
$$

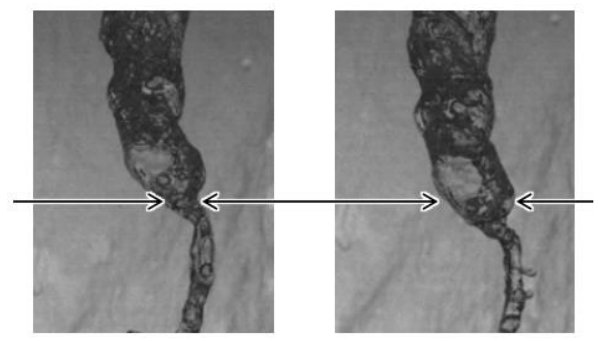

(a) $W$ at $t-\Delta t$

(b) $W$ at $t$

Photo 5 Measurement of the jet width $W$.

ここで、W(t,L)と $W(t-\Delta t, L)$ は、Photo 5 に示すよ うに、同じ位置の高速度カメラを用いた撮影で近 接する 2 時刻における噴流の幅を表す。 $\Delta t$ の值 は、ノズル直径 $D$ を全体積流束 $J_{l}+J_{g}$ で除して得 られる時間スケールの程度で、12〜20 $\mathrm{ms}$ の範囲 とした。 $f_{\text {def }}$ は $L$ の関数だが、時間的にも変化し、 噴流の変形が最も激しいときに液滴飛散も最も 激しくなると考えられる。このため、 $f_{\text {def }}$ の時間に 関する最大值を各位置における気液二相噴流の 変形率 $F_{\text {def }}$ とした。

代表的な実験条件で計測された $F_{\text {def }}$ と $S p^{*}$ の関
係を Fig. 6 に示す。今後、気液の流量条件や物性 值等の条件を拡大して実験を行うことで、より汎 用性の高い $f_{\text {def }}$ の定義式を導く必要があるが、本 実験の範囲では、噴流の変形率 $F_{\text {def }}$ が $80 \mathrm{~s}^{-1}$ 程度 を超過すると、液滴飛散を開始している。すなわ ち、気液二相噴流が固体壁に衝突したときに、液 滴飛散を生じるか否かは、噴流の変形率から判断 することが可能と考えられる。

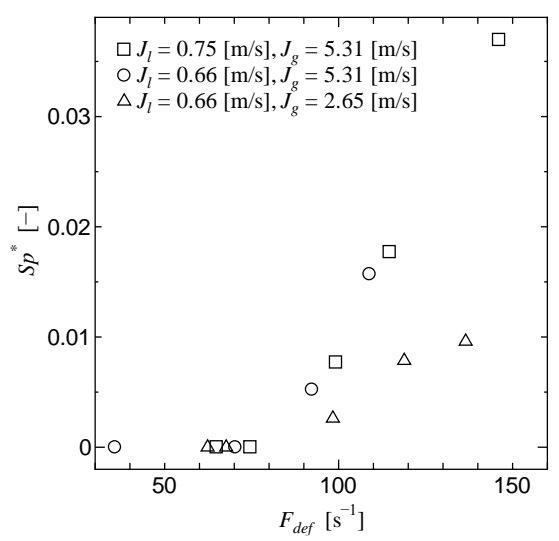

Fig. 6 Relationship between the jet deformation factor $F_{d e f}$ and the splash rate $S p^{*}$.

\section{3 変形開始長さの相関}

Zhan ら[9]は、Fig. 5 に示寸最小分裂長さ $L_{1}$ が、 ノズル出口における環状液膜の厚さ $\delta$ と比例関係 にあることを示した。このより、 $L_{d}$ と $\delta$ の間にも、 何らかの相関関係があると考えられる。まず、ノ ズルの直径を $D$ とすれば、ノズル出口で液相と 気相の平均速度 $U_{l}, U_{g}$ は次の関係を満足する。

$$
4 \delta(D-\delta) U_{l}=D^{2} J_{l}
$$

$$
(D-2 \delta)^{2} U_{g}=D^{2} J_{g}
$$

Okawa ら[10]が環状流中の液滴流量比に関する相 関式を導いた場合と同様に、液膜の内表面に作用 する界面せん断力と液膜の外表面に作用する壁 面せん断力が釣り合うとすれば次式を得る。

$$
(D-2 \delta) f_{i} \rho_{g}\left(U_{g}-U_{l}\right)^{2}=D f_{w} \rho_{l} U_{l}^{2}
$$

ここで、 $f_{i}$ は液膜内面の界面摩擦係数、 $f_{w}$ は壁面 摩擦係数、 $\rho_{g}$ と $\rho_{l}$ は各々気体と液体の密度である。 $f_{i}$ と $f_{w}$ は次に示寸 Wallisの式[11]により評価する。 


$$
\begin{aligned}
& f_{i}=0.005\left(1+300 \frac{\delta}{D}\right) \\
& f_{w}=\max \left[\frac{16}{R e}, 0.005\right]
\end{aligned}
$$

ここで、式(7)中の Reynolds 数は $R e=\rho_{\mathrm{l}} J_{1} D / \mu_{\mathrm{l}}$ で定 義される。また、 $\mu_{l}$ は液相の粘性係数である。式 (3)〜(7)を用いて繰り返し計算を行うことにより、 ノズル出口における液膜厚さ $\delta$ を計算できる。

本実験で得られた $\delta$ と $L_{d}$ の関係を Fig. 7 に示す。 ここで、 $\delta$ は式(3)〜(7)による計算值であり、 $L_{d}$ は $F_{\text {def }}=80 \mathrm{~s}^{-1}$ となる位置を画像解析により求めた。 本図より、 $L_{1}$ と同様に、 $L_{d}$ も $\delta$ と概水比例関係に あり、次式で相関できることがわかる。

$$
L_{d}=28.5 \delta
$$

ここで、Zhan ら[9]は、 $L_{1}$ が $\delta$ の 59 倍程度と報告 していることから、上式より、 $L_{d}$ は $L_{1}$ の半分程 度であることがわかる。

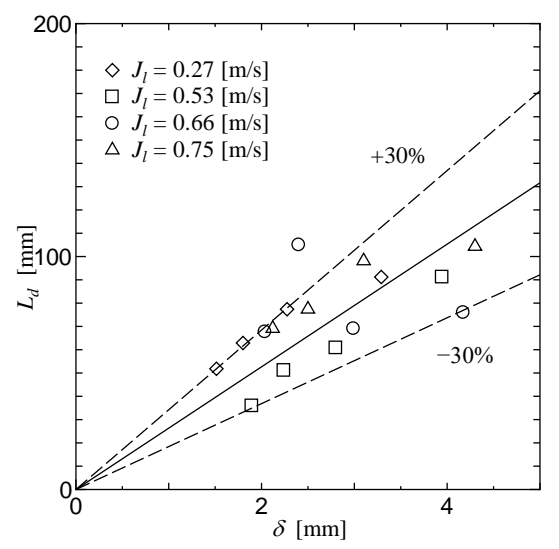

Fig. 7 Dependence of the deformation length $L_{\mathrm{d}}$ on the liquid film thickness at the nozzle $\delta$.

次に、 $L_{d}$ と $\delta$ が概ね比例関係にあることから、 $\delta$ は $L_{d}$ のスケーリングパラメーターとして適当と 言える。一方、単相噴流の場合には、Photo 1 に 示すように、分裂前の噴流の変形は顕著ではない。 これより、気液二相噴流の変形は、主に環状液膜 の内部を流れる気流のせん断力によって引き起 こされていると考えられる。以上の考察に基づき、 無次元変形開始長さを $L_{d} / \delta$ で定義し、次式で定 義される Weber 数との関係を調べた。

$$
W e=\frac{\rho_{g}\left(U_{g}-U_{l}\right)^{2} \delta}{\sigma}
$$

ここで、 $\sigma$ は表面張力を表す。 $L_{d} / \delta$ と We の関係 をFig. 8 に示す。今後、流体の物性值、特に液体 の表面張力の影響を調査する必要があると考え られるが、Fig. 8 によれば、Weの影響は明確には 認められない。したがって、本実験条件の範囲で は、気液二相噴流の変形開始長さに関する相関式 として、式(8)が推奨される。

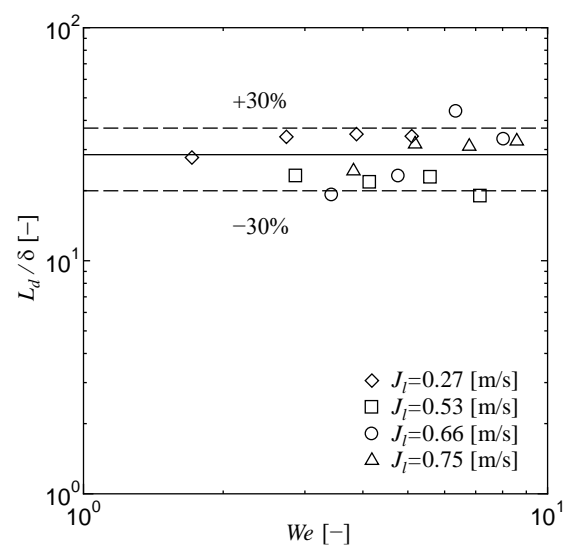

Fig. 8 Dependence of the dimensionless deformation length $L_{d} / \delta$ on the Weber number $W e$.

\section{4. 結 言}

気液二相噴流が固体面に衝突する際に発生す る飛散液滴の総量と径分布を予測することを最 終目的として、本研究では、主に気液二相噴流の 変形開始長さについて実験的に検討した。得られ た結論を以下に示す。

・ 気液二相噴流は、分裂を生じる前から激しく 変形する。変形部分が固体面上に形成された 液膜に衝突すると、噴流の分裂により形成さ れた一次液滴が衝突する場合と類似の状況と なり、顕著な液滴飛散を引き起こす。

・ 顕著な液滴飛散を生じるときの二相噴流の変 形の程度を表す尺度として、単位時間当たり の噴流幅の変化率が使用できる可能性を示し た。

・ 顕著な液滴飛散を生じる程度まで二相噴流が 変形するのに要するノズルからの距離（変形 開始長さ）は、最小分裂長さと同様に、ノズ 
ル部における環状液膜の厚さと比例関係にあ ることを示した。なお、変形開始長さは最小 分裂長さの半分程度で、Weber 数に対する依 存性は、明確には認められなかった。

本研究では、気液の流量を系統的に変更して実 験データを収集したが、ノズルの径と長さ、流体 の物性值、気液の混合形態等は一定とした。この ため、今後、これらの物理量の影響、特に液相の 表面張力の影響を調査することが重要と考えら れる。また、噴流の流出方向を鉛直下向きとした が、実機では水平に近い角度で噴射される。この ため、噴射角度の影響解明も今後の検討課題であ る。

\section{Nomenclature}

$J \quad$ : superficial velocity

$L_{1} \quad$ : minimum breakup length

$L_{d} \quad$ : deformation length

$W \quad$ : jet width

$f_{\text {def }} \quad$ : deformation factor

$F_{\text {def }} \quad:$ maximum value of $f_{\text {def }}$

$Q \quad$ : mass flow rate

$S^{*} \quad:$ splash rate

$U \quad$ : velocity at nozzle

We : Weber number

$[\mathrm{m} / \mathrm{s}]$

\section{Greek letters}

$\delta \quad:$ liquid film thickness

[m]

$\rho \quad$ : density

$\left[\mathrm{kg} / \mathrm{m}^{3}\right]$

\section{Subscripts}

$$
\begin{array}{ll}
d & : \text { deformation } \\
g & : \text { gas phase } \\
l & : \text { liquid phase } \\
\text { splash } & : \text { splashed droplets }
\end{array}
$$

\section{参考文献}

[1] Okawa, T., Shiraishi, T. and Mori, T., Production of Secondary Drops during the Single Water Drop Impact onto a Plane Water Surface, Experiments in Fluids, Vol. 41, 965-974 (2006).

[2] Kim, Y., Amagaya, K., Ogiwara, G. and Arai, M., Wall Impingement Phenomena of a Liquid Jet (in Japanese), ILASS-Japan Vol. 9(26), 10-17 (2000).

[3] Rayleigh, L., On the Instability of Jets, Proceedings of the London Mathematical Society, Vol. s1-10(1), 4-13 (1878).

[4] Lin, S. P. and Reitz, R. D., Drop and Spray Formation from a Liquid Jet, Annual Review of Fluid Mechanics, Vol. 30, 85-105 (1998).

[5] Cheong, B. S. and Howes, T., Capillary Jet Instability under the Influence of Gravity, Chemical Engineering Science Vol. 59, 21452157 (2004).

[6] Zhan, Y., Oya, N., Enoki, K., Okawa, T., Aoyagi, M. and Takata, T., Droplet Generation during Liquid Jet Impingement onto a Horizontal Plate, Exp. Therm Fluid Sci., Vol. 98, 86-94 (2018).

[7] Zhan, Y., Kuwata, Y., Maruyama, K., Okawa, T., Enoki, K., Aoyagi, M. and Takata, T., Effect of Surface Tension and Viscosity on Liquid Jet Breakup, Exp. Thermal and Fluid Sci., Vol. 112, 109953 (2020).

[8] Zhan, Y., Kuwata, Y., Okawa, T., Aoyagi, M. and Takata, T., Experimental Study on Secondary Droplets Produced during Liquid Jet Impingement onto a Horizon Solid Surface, Exp. Thermal and Fluid Sci., Vol. 120, 110249 (2021).

[9] Zhan, Y., Sun G., Okawa, T. and Irikura, M., A Study on Droplet Carryover in Gas-Liquid Separator (Experimental Investigation on the Minimum Breakup Length of Two-Phase Fluid Jet), Japanese Journal of Multiphase Flow, Vol. 34(1), 75-81 (2020).

[10] Okawa, T., Kitahara, T., Yoshida, K., Matsumoto, T. and Kataoka, I., New Entrainment Rate Correlation in Annular Two-Phase Flow Applicable to Wide Range of Flow Condition, Int. J. Heat Mass Transfer, Vol. 45, 87-98 (2002).

[11] Wallis, G. B., Phenomena of Liquid Transfer in Two-Phase Dispersed Annular Flow, Int. J. Heat Mass Transfer, Vol. 11, 783-785 (1968). 